Volume 4 • Nomor 1 • Oktober 2020

Pege (Hal.) : 1 - 12

(C) Universitas Pamulang

JL.Surya Kencana No.1 Pamulang, Tangerang Selatan - Banten

Telp. (021) 7412566, Fax (021) 7412491

website. :

rnalmarketing.unpam@gmail.com

\title{
The Formation of Customer Loyalty From Brand Awareness and Perceived Quality through Brand Equity of Xiaomi Smartphone Users in South Tangerang
}

\author{
Rosa Lesmana ${ }^{1}$, Arief Siaha Widodo ${ }^{2,}$ Nardi Sunardi $^{3}$ \\ ${ }^{123}$ University of Pamulang \\ 1dosen01360@unpam.ac.id; ${ }^{2}$ dosen01725@unpam.ac.id
}

\begin{abstract}
The purpose of this research was to determine the effect of Brand Awareness and Perceived Quality on Brand Equity, the effect of Brand Equity on Customer Loyalty, and to find out whether Brand Equity mediates between Brand Awareness and Perceived Quality on Customer Loyalty of the Xiaomi smartphone user in South Tangerang area. The type of the research is quantitative using the factor analysis method, and SEM and the tools used SPSS Amos 23. The unit of analysis in this study is the consumer who uses the Xiaomi smartphone in South Tangerang area. The research design is single cross sectional, a sample size of 150 respondents. The results show that brand awareness does not have a significant effect on brand equity on Xiaomi smartphones in South Tangerang area with a regression coefficient value of -.730 and critical ratio value -1.183 . Perceived quality has a significant effect on brand equity on Xiaomi smartphone in the South Tangerang area with a regression coefficient of 0.964 and a critical ratio value of 4,450 . Brand equity has a significant effect on customer loyalty of the Xiaomi smartphone in the South Tangerang area with a regression coefficient of 0.590 and a critical ratio value of 5,373. Brand awareness has no significant effect on customer loyalty on the Xiaomi smartphones in the South Tangerang area with a regression coefficient of 0.608 and a critical ratio value of 1.343. Perceived quality has no significant effect on customer loyalty of the Xiaomi smartphones in South Tangerang area with a regression coefficient of -0.164 and a critical ratio value of -0.880 . Brand awareness indirectly has no significant effect on customer loyalty through brand equity on the Xiaomi smartphones in South Tangerang area with a regression coefficient of -0.181 and the Sobel test result of $-3,000$. Perceived quality indirectly has a significant effect on customer loyalty through brand equity on the Xiaomi smartphones in South Tangerang area with a regression coefficient of 0.663 and the results of the Sobel test of 20,165
\end{abstract}

Key word: Brand Awareness; Perceived Quality: Brand Equity; Customer Loyalty 


\section{A. INTRODUCTION}

Indonesia is one of the countries with the largest smartphone user growth, behind China and India, the three countries will collectively add more than 400 million new smartphone users from 2013 to 2018. (Maulidina \& Ariyanti S, Vol.3, No.2 Agustus 2016).

The emergence of smart phone technology has made marketers compete to create superior smartphone products, so there are more choices from various brands and the competition is getting tougher. The number of choices has made increasing the demand for smartphones but consumer loyalty to a particular smartphone brand tends to decline. (Roza, Erida, \& Shinta, 2015). There are currently five smartphone brands that dominate the market in Indonesia.

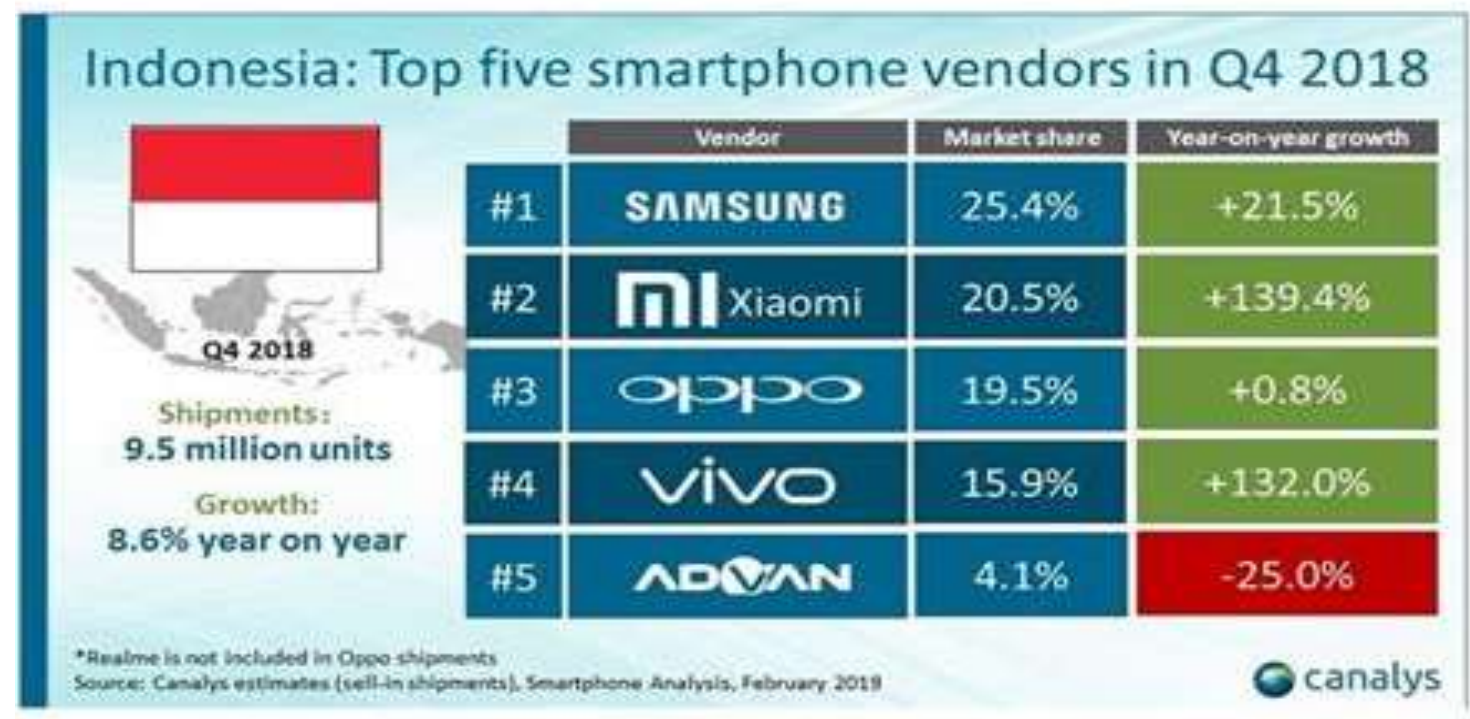

Source: inet.detik.com

Picture 1: Top 5 Smartphone brand in Indonesia 2018

The top 5 brands that dominate the smartphone market in Indonesia for the year of 2018 are as follows: Samsung brand is still in the first position but there has been a decline in market share from $30 \%$ to $25,4 \%$ in 2018 , a decline of $4.6 \%$. Meanwhile, the second position is held by Xiaomi with a market share that has increased dramatically from $6.2 \%$ to $20.5 \%$ or an increase of $14.3 \%$. Oppo is in the third position, where the market share has decreased by $6 \%$, from $25.5 \%$ to $19.5 \%$. Vivo is in the fourth position, where there was an increase in market share of $8.4 \%$ from $7.5 \%$ to $15.9 \%$. Advan occupies the fifth position, with a $4.2 \%$ decline in market share. The phenomenon of increasing the share of the Xiaomi smartphone market in Indonesia has increased sharply, from the fifth rank in 2017 with a market share of only $6.2 \%$ to $20.5 \%$ in 2018 . We can see that only the top 5 brands dominate the market, while the users in Indonesia are very large, with the number of increases as follows: 


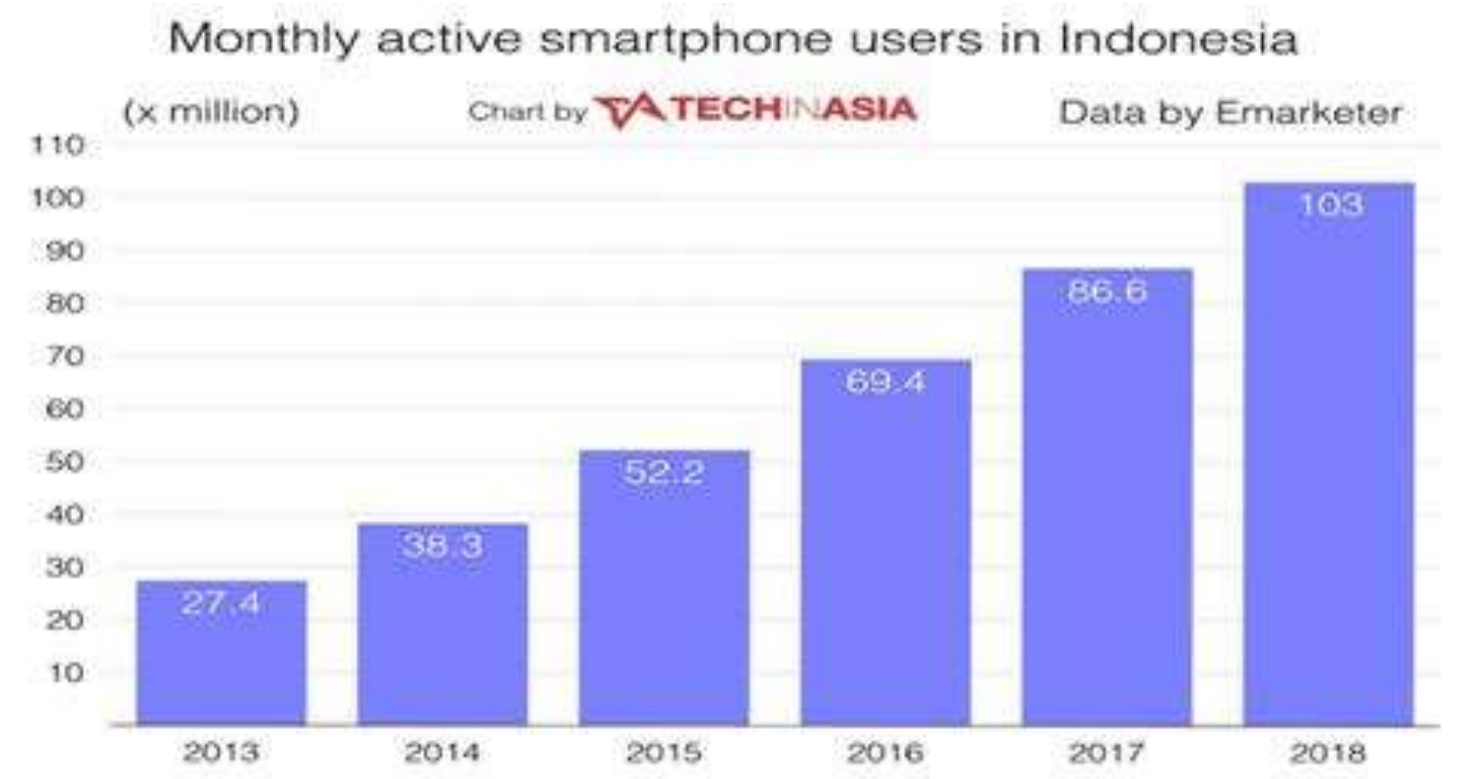

Source : inet.detik.com

\section{Picture 2 : Smartphone users increasing for the period of 2013 to 2018}

From the above graph, it can be seen that the number of active smartphone users from 2013 to 2018 continues to increase. The phenomenon and trends of smartphone users in Indonesia are increasing from year to year. In 2014 there was an increase of $10.9 \%$, in 2015 it increased by $13.9 \%$. peaks in 2016 and 2017 where there was an increase of $17.2 \%$, while in 2018 there was an increase of $16.4 \%$.

Based on the above description, the author is interested in conducting research with the title "The Formation of Customer Loyalty From Brand Awareness and Perceived Quality through Brand Equity of Xiaomi Smartphone Users in South Tangerang".

\section{Research purposes}

1. To determine the effect of Brand Awareness (BA) on Brand Equity (BE) on Xiaomi Smartphone users in the South Tangerang area?

2. To determine the effect of Perceived Quality (PQ) on Brand Equity (BE) on Xiaomi Smartphone users in the South Tangerang area?

3. To determine the effect of Brand Equity (BE) on Customer Loyalty (CL) on Xiaomi Smartphone users in the South Tangerang area?

4. To determine the effect of Brand Awareness (BA) on Customer Loyalty (CL) on Xiaomi Smartphone users in the South Tangerang area?

5. To determine the effect of Perceived Quality (PQ) on Customer Loyalty (CL) on Xiaomi Smartphone users in the South Tangerang area?

6. To find out whether Brand Equity (BE) mediates between Brand Awareness (BA) and Customer Loyalty $(\mathrm{CL})$ on Xiaomi Smartphone users in the South Tangerang area?

7. To find out whether Brand Equity (BE) mediates between Perceived Quality and Customer Loyalty $(\mathrm{CL})$ for Xiaomi Smartphone users in the South Tangerang area? 


\section{B. LITERATURE REVIEW}

Brand Equity according to Aaker (Aaker, 2005) "is a set of brand assets and liabilities associated with a brand, its name and symbol which is able to increase or decrease the value provided by a product both to the company and to consumers".

According to (Alghofari, Pratiwi, \& Astuti, 2009) in their research, Brand Equity is a set of brand assets and liabilities associated with a brand, name, and symbol that a product or service provides to consumers.

Five category of Brand Equity :

1. Brand Loyalty

2. Brand Awarness

3. Perceived quality

4. Brand Associations

5. Other proprietary brand assets.

According to (Mowen \& Minor, 2001) that loyalty can be based on the actual purchasing behavior of the product which is associated with the proportion of purchases". (Oliver, 1999) "defines brand loyalty as a deep commitment to make a consistent repurchase of preferred products or services in the future by repurchasing the same brand even though there are situational influences and marketing efforts that can lead to shifting behavior. ".

\section{RESEARCH METHODOLOGY}

This type of research is quantitative using the factor analysis method, SEM and the SPSS Amos 23 test tool. The unit of analysis in this study is the consumer who uses the Xiaomi brand smartphone in the South Tangerang area. The research design used was single cross sectional, with a sample size of 150 respondents

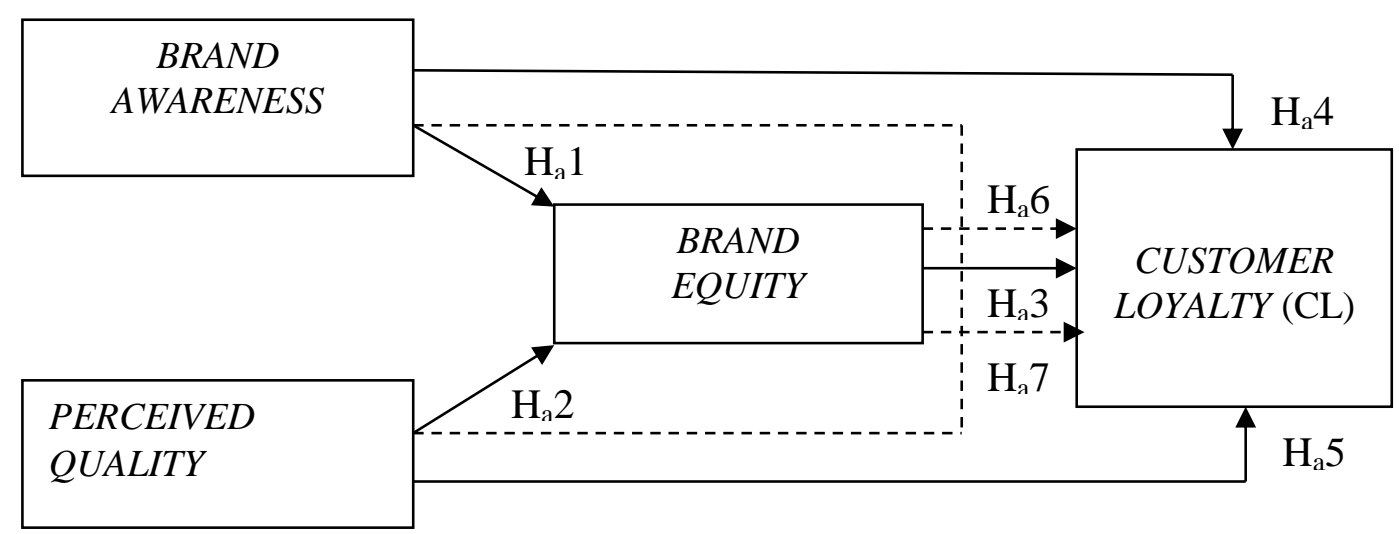

Picture 3 : Research Model 


\section{RESULT AND DISCUSSION}

Desciptive analysis are as below :

Table 1 : Descriptive Analysis of Brand Awareness

\begin{tabular}{|c|c|c|c|}
\hline & Variabel/Instrumen & Rata-rata & Kategori \\
\hline & $\begin{array}{l}\text { The smartphone of the Xiaomi brand } \\
\text { has memorable characteristics }\end{array}$ & 3.95 & Good \\
\hline $\begin{array}{l}\text { Brand } \\
\text { Awareness }\end{array}$ & $\begin{array}{l}\text { The smartphone of Xiaomi brand are } \\
\text { easy to recognize compared to other } \\
\text { brands }\end{array}$ & 3.78 & Good \\
\hline & $\begin{array}{l}\text { The smartphone of the Xiaomi brand } \\
\text { is always in the memory of } \\
\text { consumers }\end{array}$ & 3.68 & Good \\
\hline & Average scor of Brand Awareness & 3.80 & Good \\
\hline
\end{tabular}

Source : Data analysis, 2020

Table 1 informs that the Brand Awareness of the Xiaomi brand smartphone is in good category with average score of 3.80 .

Table 2 : Descriptive analysis of Perceived Quality

\begin{tabular}{|l|l|c|c|}
\hline \multicolumn{2}{|c|}{ Variabel/Instrumen } & $\begin{array}{c}\text { Rata-rata } \\
\text { Skor }\end{array}$ & Kategori \\
\hline $\begin{array}{l}\text { Perceived } \\
\text { Quality }\end{array}$ & $\begin{array}{l}\text { The smartphone of the Xiaomi brand } \\
\text { has a good quality }\end{array}$ & 3.67 & Good \\
\cline { 2 - 4 } & $\begin{array}{l}\text { Smartphone merek Xiaomi memiliki } \\
\text { reputasi yang baik }\end{array}$ & 3.74 & Good \\
\cline { 2 - 4 } & $\begin{array}{l}\text { Smartphone merek Xiaomi memiliki } \\
\text { manfaat dan nilai yang tinggi }\end{array}$ & 3.71 & Good \\
\hline \multicolumn{2}{|l|}{ Average Score of Perceived Quality } & $\mathbf{3 . 7 0}$ & Good \\
\hline
\end{tabular}

Source : Data analysis, 2020

Table 2 informs that perceived quality of smartphone Xiaomi brand is in Good category with average score of 3.70 . 
ISSN NO. (PRINT) 2598-0823, (ONLINE) 2598-2893

Table 3 : Descriptive analysis of Brand Equity

\begin{tabular}{|l|l|c|c|}
\hline \multicolumn{2}{|c|}{ Variabel/Instrumen } & $\begin{array}{c}\text { Rata-rata } \\
\text { Skor }\end{array}$ & Kategori \\
\hline $\begin{array}{l}\text { Brand } \\
\text { Equity }\end{array}$ & $\begin{array}{l}\text { The Xiaomi brand smartphone } \\
\text { match to my personality }\end{array}$ & 3.31 & Un Good \\
\cline { 2 - 4 } & $\begin{array}{l}\text { I feel proud to use a Xiaomi brand } \\
\text { Smartphone }\end{array}$ & 3.13 & Un Good \\
\cline { 2 - 4 } & $\begin{array}{l}\text { I feel happy to use Xiaomi } \\
\text { Smartphone brand }\end{array}$ & 3.41 & Good \\
\hline \multicolumn{2}{|l|}{ Average Score of Skor Brand Equity } & $\mathbf{3 . 2 8}$ & Un Good \\
\hline
\end{tabular}

Source : Data Analysis, 2020

Table 3 informs that brand equity of Xiaomi smartphone brand is in Un Good Category with average score of 3.28

Table 4 : Descriptive Analysis of Customer Loyalty

\begin{tabular}{|l|l|c|c|}
\hline \multicolumn{2}{|c|}{ Variabel/Instrumen } & $\begin{array}{c}\text { Rata-rata } \\
\text { Skor }\end{array}$ & Kategori \\
\hline $\begin{array}{l}\text { Customer } \\
\text { Loyalty }\end{array}$ & $\begin{array}{l}\text { Willing to pay higher for Xiaomi } \\
\text { brand smartphones than other } \\
\text { brands }\end{array}$ & 2.45 & Un Good \\
\cline { 2 - 4 } & $\begin{array}{l}\text { Committed to continue choosing } \\
\text { the Xiaomi brand smartphone } \\
\text { over other brands }\end{array}$ & 2.89 & Un Good \\
\cline { 2 - 4 } & $\begin{array}{l}\text { Stay true to Xiaomi brand } \\
\text { Smartphones }\end{array}$ & 2.95 & Un Good \\
\hline \multicolumn{2}{|l|}{ Rata-rata Skor Customer Loyalty } & $\mathbf{2 . 7 5}$ & Un Good \\
\hline
\end{tabular}

Source : Data Analysis, 2020

Table 4 informs that customer Loyalty of Xiaomi brand smartphone is in un good category with average score of 2.75 
ISSN NO. (PRINT) 2598-0823, (ONLINE) 2598-2893

\section{Confirmatory Factor Analysis}

Table 5 : Result of CFA Models test

\begin{tabular}{|c|c|c|c|c|}
\hline Variabel & Pernyataan & Loading & Kriteria & Kesimpulan \\
\hline \multirow[t]{3}{*}{$\begin{array}{l}\text { Brand } \\
\text { Awareness }\end{array}$} & $\begin{array}{l}\text { The smartphone of the } \\
\text { Xiaomi brand has } \\
\text { memorable } \\
\text { characteristics }\end{array}$ & 0.40 & \multirow{10}{*}{0,30} & Valid \\
\hline & $\begin{array}{l}\text { The smartphone of } \\
\text { Xiaomi brand are easy to } \\
\text { recognize compared to } \\
\text { other brands }\end{array}$ & 0.34 & & Valid \\
\hline & $\begin{array}{l}\text { The smartphone of the } \\
\text { Xiaomi brand is always } \\
\text { in the memory of } \\
\text { consumers }\end{array}$ & 0.80 & & Valid \\
\hline \multirow[t]{3}{*}{$\begin{array}{l}\text { Perceived } \\
\text { Quality }\end{array}$} & $\begin{array}{l}\text { The smartphone of the } \\
\text { Xiaomi brand has a good } \\
\text { quality }\end{array}$ & 0.89 & & Valid \\
\hline & $\begin{array}{l}\text { Smartphone merek } \\
\text { Xiaomi memiliki reputasi } \\
\text { yang baik }\end{array}$ & 0.77 & & Valid \\
\hline & $\begin{array}{l}\text { Smartphone merek } \\
\text { Xiaomi memiliki manfaat } \\
\text { dan nilai yang tinggi }\end{array}$ & 0.76 & & Valid \\
\hline \multirow[t]{3}{*}{$\begin{array}{l}\text { Brand } \\
\text { Equity }\end{array}$} & $\begin{array}{l}\text { The Xiaomi brand } \\
\text { smartphone match to my } \\
\text { personality }\end{array}$ & 0.82 & & Valid \\
\hline & $\begin{array}{l}\text { I feel proud to use a } \\
\text { Xiaomi brand } \\
\text { Smartphone }\end{array}$ & 0.88 & & Valid \\
\hline & $\begin{array}{l}\text { I feel happy to use } \\
\text { Xiaomi Smartphone } \\
\text { brand }\end{array}$ & 0.82 & & Valid \\
\hline \multirow[t]{3}{*}{$\begin{array}{l}\text { Customer } \\
\text { Loyalty }\end{array}$} & $\begin{array}{l}\text { Willing to pay higher for } \\
\text { Xiaomi brand } \\
\text { smartphones than other } \\
\text { brands }\end{array}$ & 0.66 & & Valid \\
\hline & $\begin{array}{l}\text { Committed to continue } \\
\text { choosing the Xiaomi } \\
\text { brand smartphone over } \\
\text { other brands }\end{array}$ & 0.92 & \multirow[t]{2}{*}{0,30} & Valid \\
\hline & $\begin{array}{l}\text { Stay true to Xiaomi } \\
\text { brand Smartphones }\end{array}$ & 0.93 & & Valid \\
\hline
\end{tabular}

Source: Data analysis Amos 23, 2020 
0,3

Tabel 5 informs that all of the indicator are valid with standard loading factor value >

Table 6 : AVE dan CR Evaluation Value

\begin{tabular}{|c|c|c|c|c|c|c|}
\hline No & Variabel & AVE & Kriteria & CR & Kriteria & Kesimpulan \\
\hline 1 & $\begin{array}{l}\text { Brand } \\
\text { Awareness }\end{array}$ & 0.32 & \multirow{4}{*}{$\begin{array}{l}\text { AVE } \geq \\
0,30\end{array}$} & 0.53 & \multirow{4}{*}{$\begin{array}{l}C R \geq \\
0,50- \\
0,70\end{array}$} & Valid and Reliabel \\
\hline 2 & $\begin{array}{l}\text { Perceived } \\
\text { Quality }\end{array}$ & 0.65 & & 0.85 & & Valid and Reliabel \\
\hline 3 & Brand Equity & 0.70 & & 0.87 & & Valid and Reliabel \\
\hline 4 & $\begin{array}{l}\text { Customer } \\
\text { Lyalty }\end{array}$ & 0.71 & & 0.88 & & Valid and Reliabel \\
\hline
\end{tabular}

Source: Data analysis Amos 23, 2020

Table 6 describe that all variable have Average Varians Extract (AVE) value $>0,30$ and Construct Reliability (CR) value $>0,50-0,070$ it can be conclude that all variable are Valid and Reliabel.

\section{Goodness of Fit}

Table 7 : Goodness of Fit

\begin{tabular}{|l|c|c|c|}
\hline \multicolumn{1}{|c|}{ Criteria } & Model Result & Critical Value & $\begin{array}{c}\text { Model } \\
\text { Evaluation }\end{array}$ \\
\hline $\begin{array}{l}\text { Chi-Square } X^{2} \\
\text { CMIN }\end{array}$ & 52.143 & $\begin{array}{l}\text { Besar, } X^{2} \text { dengan } \\
\mathrm{df}=48 \text { adalah } 61,66\end{array}$ & Feed \\
\hline Probability (P) & 0.316 & $\geq 0.05$ & Feed \\
\hline $\begin{array}{l}X^{2} \text { Relatif } \\
(\text { CMIN/DF) }\end{array}$ & 1.086 & $\leq 2.0$ & Feed \\
\hline GFI & 0.946 & $\geq 0.90$ & Feed \\
\hline AGFI & 0.912 & $\geq 0.90$ & Feed \\
\hline TLI & 0.994 & $\geq 0.95$ & Feed \\
\hline CFI & 0.996 & $\geq 0.95$ & Feed \\
\hline RMSEA & 0.024 & $\leq 0.08$ & Feed \\
\hline
\end{tabular}

Source: Data analysis Amos 23, 2020

Confirmatory Factor Analysis of measurement model for this research shows that the model is feed, with GFI, AGFI value $\geq 0.9$; TLI and CFI value are also $\geq 0,95$; RMSEA $0,024 \leq 0,08$ and also for others criteria are in feed criteria 


\section{SEM model with Amos 23 program}

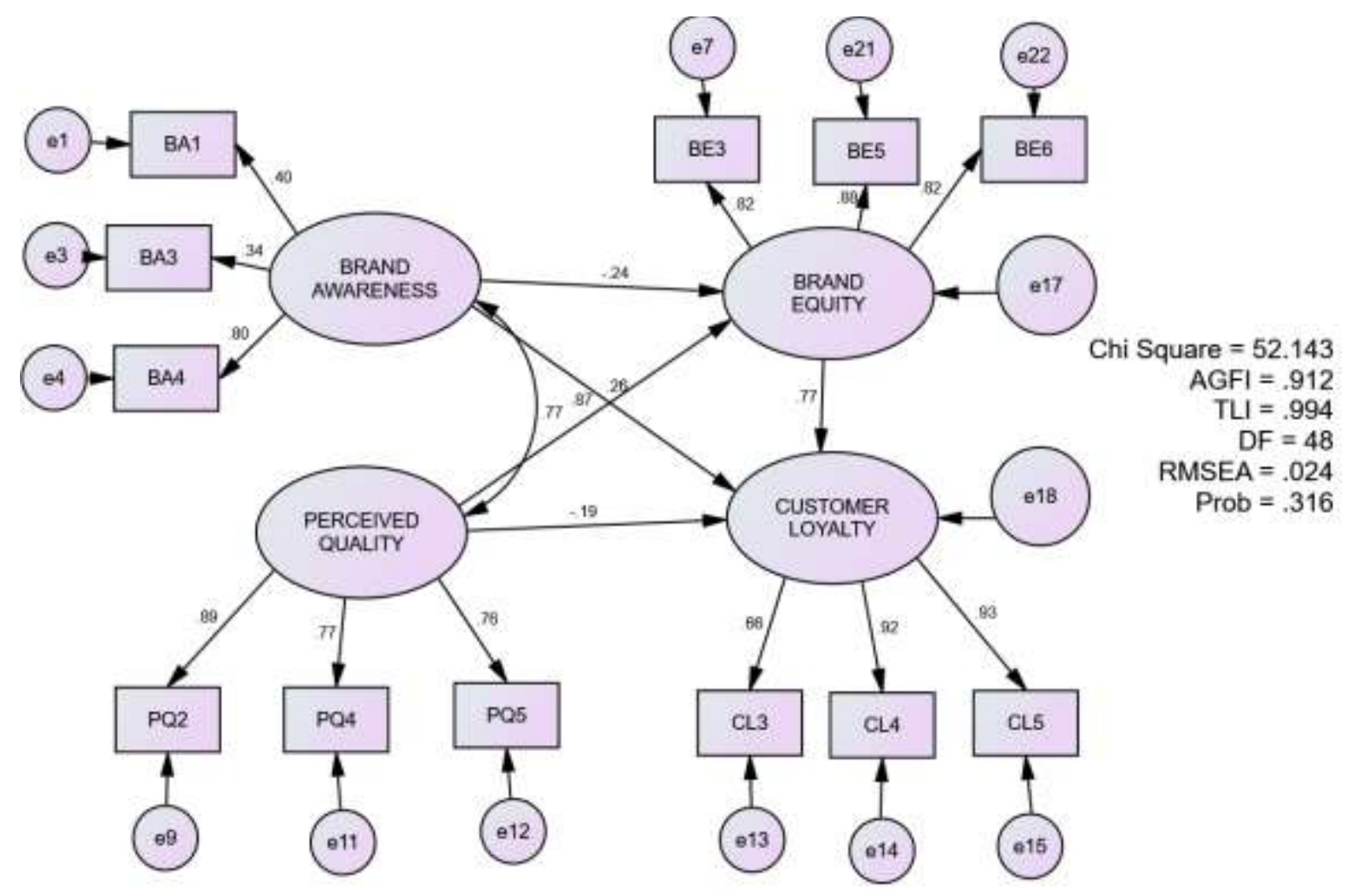

Picture 4 : SEM Standardized Model

Table 8 : Statistic Test for direct effect Regression Weights

\begin{tabular}{|l|c|c|c|c|c|}
\hline \multicolumn{1}{|c|}{$\begin{array}{c}\text { Regression } \\
\text { Weight }\end{array}$} & Estimate & $\begin{array}{c}\text { Standardise } \\
\text { d Estimate }\end{array}$ & C.R & P & Result \\
\hline $\begin{array}{l}\text { Brand Equity <--- } \\
\text { Brand Awareness }\end{array}$ & -.730 & .617 & -1.183 & .237 & Not Significant \\
\hline $\begin{array}{l}\text { Brand Equity<--- } \\
\text { Perceived Quality }\end{array}$ & .964 & .217 & 4.450 & $* * *$ & Significant \\
\hline $\begin{array}{l}\text { Customer_Loyalty } \\
\text { <-- Brand_Equity }\end{array}$ & .590 & .110 & 5.373 & $* * *$ & Significant \\
\hline $\begin{array}{l}\text { Customer_Loyalty } \\
\text { <-- } \\
\text { Brand_Awareness }\end{array}$ & .608 & .453 & 1.343 & .179 & Not Significant \\
\hline $\begin{array}{l}\text { Customer_Loyalty } \\
\text { <-- } \\
\text { Perceived_Quality }\end{array}$ & -.164 & .186 & -.880 & .379 & Not Significant \\
\hline
\end{tabular}

Source: Data analysis Amos 23, 2020 
The Regression Weight test above shows a direct effect on 5 hypotheses, there are 2 hypotheses that have a significant effect, namely: $\mathrm{H} 2$ with a CR value of $4.450>1.96$ and H3 with a CR value of $5.373>1.96$, while the other 3 hypotheses have no significant effect, namely: $\mathrm{H} 1$ with $\mathrm{CR}$ value $-1.183<1.96, \mathrm{H} 4$ with $\mathrm{CR}$ value $1.343<1.96$ and $\mathrm{H} 5$ with $\mathrm{CR}$ value $1.343<1.96$

\section{Table 9 : Sobel Test Indirect Effect}

\begin{tabular}{|c|c|c|c|c|}
\hline $\begin{array}{c}\text { Pengaruh Tidak } \\
\text { Langung }\end{array}$ & Estimate & Z Sobel & T Value & Result \\
\hline $\begin{array}{c}\text { Customer Loyalty < } \\
--- \text { Brand Equity <-- } \\
- \text { - Brand Awareness }\end{array}$ & -.181 & -3.000 & 1.96 & $\begin{array}{c}-3.000<1,96=\text { Not } \\
\text { Significant. }\end{array}$ \\
\hline $\begin{array}{c}\text { Customer Loyalty < } \\
--- \text { Brand Equity <-- } \\
- \text { Perceived Quality }\end{array}$ & .663 & 20.165 & 1.96 & $\begin{array}{c}20.165>1,96= \\
\text { Significant }\end{array}$ \\
\hline
\end{tabular}

Source: Data analysis Amos 23, 2020

Above sobel test results informs, it can be concluded that indirectly $\mathrm{H} 6$ has no significant effect with the $\mathrm{Z}$ value of $-3,000<1.96$ while $\mathrm{H} 7$ has a significant effect with the $Z$ value of sobel $20,165>1.96$.

\section{E. CONCLUSION AND SUGGESTION}

\section{Conclusion}

1. Brand awareness has no significant effect on brand equity on the Xiaomi brand smartphone in the South Tangerang area with a regression coefficient value of -730 and Critical Ratio -1.183.

2. Perceived quality has a significant effect on brand equity on the Xiaomi brand smartphone in the South Tangerang area with a regression coefficient of 0.964 and a critical ratio value of 4,450 .

3. Brand equity has a significant effect on customer loyalty on the Xiaomi brand smartphone in the South Tangerang area with a regression coefficient of 0.590 and a critical ratio value of 5,373 .

4. Brand awareness has no significant effect on customer loyalty on the Xiaomi brand smartphone in the South Tangerang area with a regression coefficient of 0.608 and a critical ratio value of 1.343 .

5. Perceived quality has no significant effect on customer loyalty on the Xiaomi brand smartphone in the South Tangerang area with a regression coefficient of -0.164 and a critical ratio value of -0.880 .

6. Brand awareness indirectly has no significant effect on customer loyalty through brand equity on the Xiaomi brand smartphone in the South Tangerang area with a regression coefficient of -0.181 and the Sobel test result of $-3,000$

7. Perceived quality indirectly has a significant effect on customer loyalty through brand equity on the Xiaomi brand smartphone in the South Tangerang area with a regression coefficient of 0.663 and a Sobel test result of 20,165 


\section{Suggestion}

1. To increase brand equity, the smartphones of the Xiaomi brand must increase brand awareness and perceived quality. However, improvement is more prioritized on perceived quality through quality improvement by paying attention to the instrument "Xiaomi brand smartphones have good quality".

2. To increase customer loyalty, the smartphones of the Xiaomi brand can increase brand equity, especially in the instrument "I feel proud to use the Xiaomi brand Smartphone".

3. Brand equity is statistically proven to play a role in mediating between the variable perceived quality and customer loyalty. It can be concluded that the brand equity of the smartphones of the Xiaomi brand will be formed well if the perceived quality can affect customer loyalty. So it is recommended to smartphones from the Xiaomi brand in South Tangerang area to maintain the current good perceived quality and brand awareness.

4. As input for the next research in order to add other variables in order to produce diverse and different research. 


\section{DAFTAR PUSTAKA}

Aaker, D. A. (2005). Strategic Market Management. New York,: John Wiley \& Son.

Alghofari, A. K., Pratiwi, I., \& Astuti, Y. P. (2009). Analisis Pengruh Brand Equity Terhadap Pembentukan Customer Loyalty Pada Jenis Merek Pasta Gigi. Simposium Nasional RAPI VIII 2009, 1-58.

Alvedi, M. (2017). Effect of Brand factors on customer loyalty with the mediating role of brand equity . International Academic Journal of Accounting and Financial Management, 36-46.

Chaudhuri, A., \& Holbrokk, M. B. (2001). The Chain of Effects from Brand Trust and Brand Affect to Brand Performance : The Role of Brand Loyalty. Journal of Marketing. Volume 65. Number 2, 81-93.

Chen, X., Huang, Q., \& Davidson, R. M. (2017). The role of website quality and social capital in building buyers'loyalty. International Journal of Information Management, 1563 - 1574.

Gil, R. B., Andre's, E. F., \& Salinas, M. (2007). Family as a source of consumer-based brand equity. Journal of Product \& Brand Management, 188-199.

Malhotra, N. K. (2007). Marketing Research: an Applied Orientation. 5th edition. New Jersey: Pearson Education.

Maulidina, R., \& Ariyanti S, M. (Vol.3, No.2 Agustus 2016). Analisis Ekuitas Merek Smartphone Apple dan Samsung Pada Konsumen Muda di Indonesia. e-Proceeding of Management, 1113 - 1119.

Meizan, I. M., \& Zuliestiana, A. D. (2017 ). Pengaruh Brand Equity Terhadap Customer Loyalty (Studi pada PT JNE Cabang Kantor Perwakilan Bandung). e-Proceeding of Management, 2290 - 2295.

Mowen, J. C., \& Minor, M. (2001). Consumer Behavior: A Framework. New Jersey 67458, Prentice Hall Upper Saddle River: Pearson Education.

Oliver, R. L. (1999). Whence Consumer Loyalty. Journal of Marketing, 33 - 44.

Roza, S., Erida, E., \& Shinta, S. (2015). The influence of Brand on Customer Loyalty of Smartphone Samsung Andorid Basis. Digest Marketing Vol. 1 No. 1 Juli, 2015, 58 - 64.

Shihab, M. S., \& Sukendar, A. (2009). Pengaruh Brand Trust dan Brand Equity Terhadap Loyalitas konsumen Studi Kasus pada Produk Tes Widal Merek Remel. Jurnal IImiah Manajemen Bisnis Dan Terapan, 83 - 96.

Simon, P., \& Tjokrosaputro, M. (2018). Pengaruh Brand Awareness, Perceived Quality dan Brand Trust. Jurnal Manajemen Bisnis Dan Kewirausahaan, 14 - 23.

Suyadi, M. I., \& Fanani, D. (2014). Pengaruh Brand Awarness, Brand Association, Perceived Quality dan Brand Loyalty Terhadap Brand EquityTY. Jurnal Administrasi Bisnis (JAB), 1-5.

Lesmana, R., Sunardi, N., \& Tumanggor, M. (2020). Pelatihan Manajemen dalam Meningkatkan Motivasi Siswa dan Guru SDN 84 Rejang Lebong. Jurnal Abdi Masyarakat Humanis, 1(2).

Lesmana, R. (2019). Pengaruh Kualitas Produk Dan Kualitas Pelayanan Terhadap Kepuasan Konsumen Pt. Radekatama Piranti Nusa. Jurnal Pemasaran Kompetitif, 2(2), 115-129. 